\title{
Prediksi Berat dan Harga Buah Mengunakan Sensor Visual
}

\author{
Rahmi Mahdaliza* and Budi Sugandi ${ }^{*}$ \\ ${ }^{*}$ Politeknik Negeri Batam, Batam, Indonesia \\ Electrical Engineering Department Program \\ Jl. Ahmad Yani, Batam Centre, Batam 29461, Indonesia \\ E-mail: rahmi@polibatam.ac.id, budi_sugandi@polibatam.ac.id
}

\begin{abstract}
Abstrak
Dengan sedikitnya pengetahuan tentang nama buah yang didapat sebelumnya, tidak sedikit anak-anak maupun dewasa yang tidak mengetahui jenis maupun nama suatu buah terutama jika buah tersebut adalah buah yang langka. Selain itu kebutuhan akan alat ukur sangatlah tinggi sebanding dengan kebutuhan akan bahan pangan itu sendiri. Alat ukur yang tersedia hanyalah alat ukur yang menimbang berat buah tanpa dapat memperkirakan harga. Sehingga keberadaan akan alat ukur yang dapat mengukur berat sekaligus menampilkan harga sangatlah dibutuhkan. Dalam penelitian ini dikembangkan sistem yang menjawab kebutuhan akan sistem yang dapat memprediksi berat buah dan harga buah. Proses prediksi berat buah dilakukan dengan perhitungan jumlah pixel dan dianalisa menggunakan persamaan regresi. Hasil perkiraan berat buah ini menghasilkan eror berat rata-rata 4.44\%. Sementara proses perkiraan harga buah didapat dari perkiraan bobot buah dikalikan harga per berat buah masing-masing. Hasil perkiraan harga buah ini menghasilkan eror harga buah rata-rata $5.64 \%$.
\end{abstract}

Kata kunci: prediksi berat, prediksi harga, persamaan regresi, sensor visual

\begin{abstract}
Nowadays, many of us can not recognize several kind of fruit names especially the rare fruit. Beside that, the need of measurement instrument with high accuracy is very demanded. The available measurement instrument usually only measures the weight of fruit without price prediction. Therefore, the availability of the instrument with capability to measure and predict price is very demanded. This study developed a system that can be measure a weight and predict price using visual sensor. Weight measurement was performed by calculating the pixels number and analyzing using regression equation. The experiment result shows that our system successfully predict weight with average error $4.44 \%$ and predict fruit price with average error $5.64 \%$.
\end{abstract}

Keywords: weight prediction, price prediction, regression equation, visual sensor

\section{Pendahuluan}

Dengan sedikitnya pengetahuan tentang nama buah yang didapat sebelumnya, tidak sedikit anak-anak maupun dewasa yang tidak mengetahui jenis maupun nama suatu buah terutama jika buah tersebut adalah buah yang langka. Selain itu kebutuhan akan alat ukur sangatlah tinggi sebanding dengan kebutuhan akan bahan pangan itu sendiri. Alat ukur yang tersedia hanyalah alat ukur yang menimbang berat buah tanpa dapat memperkirakan harga. Sehingga keberadaan akan alat ukur yang dapat mengukur berat sekaligus menampilkan harga sangatlah dibutuhkan.
Beberapa studi telah dikembangkan untuk memprediksi berat dan harga buah baik dalam sistem real time atau offline maupun gabungan diantara keduanya. Syaifuddin dkk [1] telah berhasil mengembangkan sistem untuk memprediksi berat buah mangga berdasarkan metode statistik regresi linier setelah proses pengolahan citra. Hasil eksperimen mereka menghasilkan error prediksi berat sebesar $3.76 \%$. Penelitian mereka hanyalah dikhususkan untuk memprediksi satu jenis buah sehingga tidak bisa digunakan untuk buah lain. Sementara Chum dkk [2] menggunakan metode regresi tak linier untuk memprediksi berat objek. Hasil prediksi mereka diukur dalam Mean Absolut Error (MAE) sebesar 0.2 gram, Root Mean Square Error 
(RMSE) $0.25 \%$ dan Mean Relative Error (MRE) $0.73 \%$. Objek yang mereka prediksi hanyalah objek tunggal sehingga tidak bisa digunakan untuk objek lain. Sangita dkk [3] mengembangkan sistem prediksi berat mangga berdasarkan Randomizes Hough Transform (RHT) dengan rata-rata eror $3.07 \%$. Mudana [4] mengembangkan sistem pengklasifikasian buah tomat berdasarkan prediksi berat buah tomat. Akurasi pengukuran yang didapatkan adalah 97\%. Adem dkk [5] mengusulkan sistem prediksi buah apel menggunakan machine learning dan pengolahan citra secara offline. Hasil eksperimen mereka menghasilkan akurasi $96.5 \%$. Beberapa penelitian yang sudah dilakukan rata-rata dibatasi oleh jenis buah yang terbatas dan sistem yang masih offline. Sementara tantangan yang ada adalah mengembangkan sistem yang dapat secara real time mendeteksi dan memprediksi berat berbagai jenis buah dengan jumlah yang bervariasi.

Untuk menjawab tantangan yang disebutkan di atas, dalam penelitian ini dikembangkan sistem yang menjawab kebutuhan akan sistem yang secara real time dapat memprediksi berat dan harga berbagai jenis buah dalam jumlah yang bervariasi. Proses awal prediksi buah adalah pendeteksian buah dengan menggunakan filter warna HSL [6,7]. Citra buah yang terdeteksi selanjutnya dikonversi kedalam citra grayscale dan citra biner untuk dilakukan pemrosesan jumlah pixel untuk masing-masing buah. Jumlah pixel yang diperoleh direlasikan dengan berat masingmasing buah menggunakan persamaan regresi. Dari persamaan regresi tersebut, proses prediksi berat dan harga buah dilakukan.

\section{Metode}

Penelitian ini akan mengembangkan sistem yang akan menjawab kebutuhan akan sistem yang dapat melakukan perkiraan berat dan harga buah. Proses perkiraan berat buah dilakukan dengan perhitungan jumlah pixel dan dianalisa menggunakan persamaan regresi. Harga buah didapat dari bobot buah dikalikan harga tiap berat buah. Tahapan selengkapnya dari metode yang digunakan dalam artikel ini dijelaskan pada Gambar 1.

Tahapan pertama dari penelitian ini adalah pengkapturan citra menggunakan kamera. Kamera akan mendeteksi citra buah untuk kemudian dilakukan pemfilteran menggunakan filter warna HSL. Citra buah yang terdeteksi kemudian ditrasformasi ke format citra lain yaitu citra gray scale dan citra biner. Penghitungan pixel dari citra buah diperoleh dari citra biner yang didapatkan. Persamaan regresi didapatkan dari hubungan antara jumlah pixel buah yang terdeteksi dan berat masing-masing buah. Dari persamaan regresi yang didapatkan, sistem akan melakukan prediksi berat dan harga dari masingmasing buah yang terdeteksi.
Filter warna HSL merupakan salah satu filter warna yang digunakan untuk membedakan satu bagian warna objek dari warna yang lain berdasarkan komposisi warna Hue (H), Saturation (S) dan Luminance (L). Komposisi HSL yang didapatkan akan mendeteksi warna dari objek yang dideteksi. Salah satu keuntungan filter warna HSL adalah dalam mendeteksi objek terutama ketika background yang berubah-ubah karena pengaruh cahaya.

Gray scaling adalah proses transformasi citra dari citra RGB ke citra gray. Citra gray merupakan citra yang setiap pixelnya hanya mempunyai satu nilai intensitas sementara citra RGB merupakan citra dengan 3 nilai intensitas yaitu Red (R), Green (G) dan Blue (B). Persamaan 1 menunjukkan konversi citra RGB ke gray scale:

$$
\text { grayscale }=0.299 R+0.587 G+0.114 B
$$

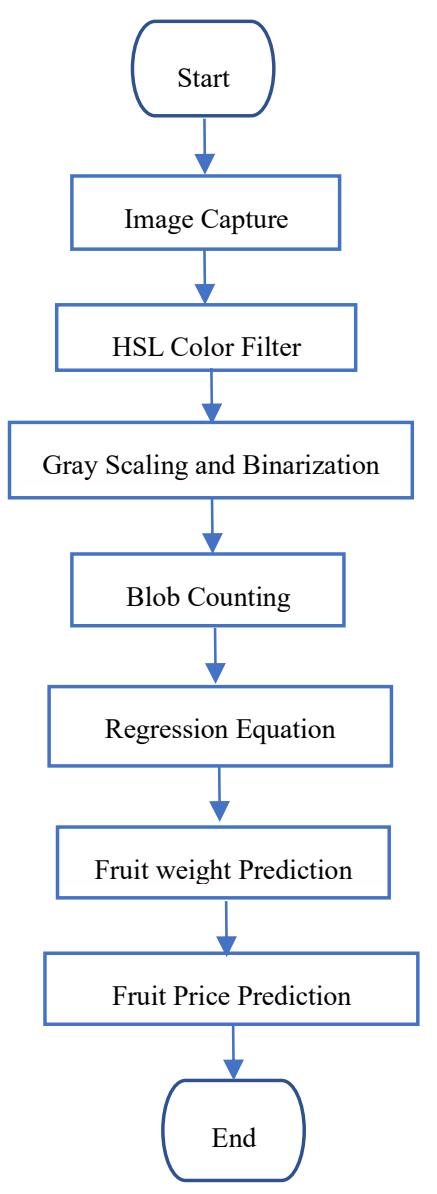

Gambar 1: Diagram alir sistem

Proses berikutnya adalah proses binarisasi yaitu proses konversi citra menjadi citra biner seperti yang ditunjukkan oleh persamaan 2 dengan $T H$ adalah nilai ambang (Threshold).

$$
\text { binarization }=\left\{\begin{array}{l}
0, \text { jika intensitas }<T H \\
1, \text { jika intensitas }>T H
\end{array}\right.
$$


Dari citra hasil binarisasi ini, proses selanjutnya adalah penghitungan jumlah pixel tiap citra buah yang dideteksi dan pengukuran berat aktual dari masingmasing buah. Hubungan antara jumlah pixel dan berat buah ini akan dihitung berdasarkan persamaan regresi. Dari persamaan regresi yang didapatkan seperti ditunjukkan dalam persamaan 3, sistem akan melakukan prediksi berat dan harga dari masingmasing buah yang terdeteksi.

$$
y=a+b x
$$

$a$ dan $b$ dihitung berdasarkan persamaan 4,

$$
b=\frac{n \sum x y-\sum x \sum y}{n \sum x^{2}-\left(\sum x\right)^{2}} \quad a=\bar{y}+b \bar{x}
$$

Jumlah buah yang terdeteksi dihitung dengan menggunakan metoda connected component labelling [7-10]. Dengan metode ini, tiap objek akan dipisahkan dan dilabeli sebagai objek yang terpisah dan berbeda.

Prediksi berat buah dilakukan berdasarkan perhitungan jumlah objek dan persamaan regresi yang didapatkan untuk masing-masing buah

\begin{tabular}{|c|c|c|c|c|c|}
\hline No & $\begin{array}{l}\text { Nama } \\
\text { Buah }\end{array}$ & $\begin{array}{c}\text { Jumlah } \\
\text { pixels }\end{array}$ & $\begin{array}{c}\text { Berat } \\
\text { (gram) }\end{array}$ & $\begin{array}{c}\text { Berat } \\
\text { rata-rata } \\
\text { (gram) }\end{array}$ & $\begin{array}{c}\text { Harga } \\
\text { (Rp) }\end{array}$ \\
\hline \multirow{4}{*}{1} & Jeruk 1 & 25100 & 176 & \multirow{4}{*}{173.75} & \multirow{4}{*}{8322.625} \\
\hline & Jeruk 2 & 23600 & 171 & & \\
\hline & Jeruk 3 & 22300 & 169 & & \\
\hline & Jeruk 4 & 26000 & 179 & & \\
\hline \multirow{4}{*}{2} & $\begin{array}{l}\text { Apel } \\
\text { merah 1 }\end{array}$ & 32000 & 231 & \multirow{4}{*}{233.25} & \multirow{4}{*}{6974.175} \\
\hline & $\begin{array}{l}\text { Apel } \\
\text { merah } 2\end{array}$ & 32000 & 236 & & \\
\hline & $\begin{array}{l}\text { Apel } \\
\text { merah } 3\end{array}$ & 26000 & 253 & & \\
\hline & $\begin{array}{l}\text { Apel } \\
\text { merah } 4\end{array}$ & 33000 & 213 & & \\
\hline \multirow{4}{*}{3} & $\begin{array}{l}\text { Apel } \\
\text { hijau } 1\end{array}$ & 7000 & 129 & \multirow{4}{*}{133} & \multirow{4}{*}{4189.5} \\
\hline & $\begin{array}{l}\text { Apel } \\
\text { hijau } 2\end{array}$ & 9000 & 135 & & \\
\hline & $\begin{array}{l}\text { Apel } \\
\text { hijau } 3\end{array}$ & 8000 & 133 & & \\
\hline & $\begin{array}{l}\text { Apel } \\
\text { hijau } 4\end{array}$ & 9000 & 135 & & \\
\hline \multirow{2}{*}{4} & Naga 1 & 54772 & 429 & \multirow{2}{*}{440} & \multirow{2}{*}{17556} \\
\hline & Naga 2 & 56395 & 451 & & \\
\hline \multirow{3}{*}{5} & Pir 1 & 23769 & 248 & \multirow{3}{*}{243.00} & \multirow{3}{*}{8383.50} \\
\hline & Pir 2 & 14894 & 238 & & \\
\hline & Pir 3 & 28566 & 243 & & \\
\hline \multirow{3}{*}{6} & $\begin{array}{l}\text { Kesemek } \\
1\end{array}$ & 22000 & 156 & \multirow{3}{*}{156.33} & \multirow{3}{*}{7504.00} \\
\hline & $\begin{array}{l}\text { Kesemek } \\
2\end{array}$ & 10000 & 145 & & \\
\hline & $\begin{array}{l}\text { Kesemek } \\
3\end{array}$ & 14000 & 168 & & \\
\hline \multirow{4}{*}{7} & Pisang 1 & 19157 & 92 & \multirow{4}{*}{88.5} & \multirow{4}{*}{3053.25} \\
\hline & Pisang 2 & 17157 & 86 & & \\
\hline & Pisang 3 & 19923 & 96 & & \\
\hline & $\begin{array}{l}\text { Pisang } 4 \\
\end{array}$ & 15145 & 80 & & \\
\hline
\end{tabular}

Tabel 1. Rekapitulasi hasil training

\section{Hasil dan Pembahasan}

Eksperimen telah dilakukan dengan beberapa jenis buah diantaranya buah jeruk, pear, buah naga, apel merah, apel hijau, pisang dan kesemek. Eksperimen dilakukan dalam dua proses yaitu proses training dan proses perhitungan.

Proses pertama adalah proses training, pada proses ini beberapa buah yang sejenis diukur berat aktualnya dan dirata-ratakan. Seperti yang ditunjukkan dalam table 1, data training tiap jenis buah diambil dari 4 biji buah, seperti 4 buah jeruk, 4 buah apel merah dan seterusnya. Jumlah pixel dan berat untuk tiap buah diukur dan ditampilkan sebagai data training. Hasil training tersebut direkap dalam tabel 1 yang menggambarkan banyaknya pixel, berat tiap buah, berat rata-rat dan harga dari masing-masing buah.

Proses selanjutnya adalah menganalisa hubungan jumlah pixel dengan berat masing-masing buah. Hubungan ini dinyatakan dalam persamaan regresi. Selanjutnya dari tabel 2 dihitung persamaan regresi untuk tiap-tiap buah dengan input adalah jumlah pixel $(x)$ dan output adalah berat buah $(y)$. Persamaan regresi yang dihasilkan ditunjukkan dalam tabel 2 . Persamaan regresi tersebut yang digunakan dalam perkiraan berat buah dengan melihat banyaknya pixel yang dikenali kamera pada masing-masing buah.

Tabel 1. Persamaan Regresi untuk tiap buah hasil

\begin{tabular}{|c|l|c|}
\multicolumn{2}{|c}{ training } \\
\hline No & $\begin{array}{l}\text { Nama } \\
\text { buah }\end{array}$ & Persamaan regresi \\
\hline 1 & Jeruk & $y=-2 E^{-10} x^{3}+E^{-5} x^{2}-0.1387 x+2760$ \\
\hline 2 & Naga & $y=0.0136 x-313.44$ \\
\hline 3 & $\begin{array}{l}\text { Apel } \\
\text { Merah }\end{array}$ & $y=-2 E^{-6} x^{2}+0.3197 x-1712.8$ \\
\hline 4 & $\begin{array}{l}\text { Apel } \\
\text { Hijau }\end{array}$ & $y=-2 E^{-6} x^{2}+0.019 x+45$ \\
\hline 5 & Pier & $y=-2 E^{-7} x^{2}+0.0073 x+165.05$ \\
\hline 6 & Pisang & $y=-2 E^{-10} x^{3}-9 E^{-6} x^{2}+0.1497 x$ \\
-796.25
\end{tabular}

Tabel 2. Perbandingan berat aktual dengan hasil prediksi

\begin{tabular}{|c|l|c|c|c|}
\hline No & $\begin{array}{c}\text { Nama } \\
\text { buah }\end{array}$ & $\begin{array}{c}\text { Berat } \\
\text { Aktual } \\
\text { (gram) }\end{array}$ & $\begin{array}{c}\text { Berat } \\
\text { Prediksi } \\
\text { (gram) }\end{array}$ & $\begin{array}{c}\text { Selisih } \\
\text { berat } \\
\mathbf{( \% )}\end{array}$ \\
\hline 1 & Jeruk & 174 & 180 & 3.45 \\
\hline 2 & Naga & 440 & 451 & 2.5 \\
\hline 3 & $\begin{array}{l}\text { Apel } \\
\text { Merah }\end{array}$ & 233 & 213 & 8.58 \\
\hline 4 & Apel & 133 & 135 & 1.50 \\
\hline
\end{tabular}




\begin{tabular}{|c|l|c|c|c|}
\hline & Hijau & & & \\
\hline 5 & Pier & 243 & 238 & 2.06 \\
\hline 6 & Pisang & 89 & 96 & 7.87 \\
\hline 7 & Kesemek & 156 & 148 & 5.13 \\
\hline \multicolumn{6}{|c|}{ Rata-rata selisih berat (\%) } & $\mathbf{4 . 4 4}$ \\
\hline
\end{tabular}

Dengan menggunakan persamaan regresi tiap buah, proses pengujian dilakukan untuk masing-masing buah. Tabel 3 menunjukkan hasil perbandingan berat buah aktual per piece dengan hasil prediksi berat buah oleh sistem. Dari hasil tersebut didapatkan selisih berat rata-rata dari hasil pengenalan adalah $4.44 \%$. Sedangkan tabel 4 menunjukkan hasil perbandingan harga buah real per piece dengan hasil pengenalan buah. Dari hasil tersebut didapatkan selisih harga ratarata dari hasil pengenalan adalah $5.64 \%$.

Tabel 4. Perbandingan harga buah aktual per piece dengan hasil prediksi

\begin{tabular}{|c|l|c|c|c|}
\hline No & $\begin{array}{c}\text { Nama } \\
\text { buah }\end{array}$ & $\begin{array}{c}\text { Harga } \\
\text { Aktual } \\
\text { (Rp) }\end{array}$ & $\begin{array}{c}\text { Harga } \\
\text { Prediksi } \\
\text { (Rp) }\end{array}$ & $\begin{array}{c}\text { Selisih } \\
\text { harga } \\
\mathbf{( \% )}\end{array}$ \\
\hline 1 & Jeruk & 8322 & 8143 & 2.15 \\
\hline 2 & Naga & 17556 & 17994.9 & 2.50 \\
\hline 3 & $\begin{array}{l}\text { Apel } \\
\text { Merah }\end{array}$ & 6974 & 6338.7 & 9.11 \\
\hline 4 & $\begin{array}{l}\text { Apel } \\
\text { Hijau }\end{array}$ & 4189 & 4252 & 1.52 \\
\hline 5 & Pier & 8383 & 7497 & 10.57 \\
\hline 6 & Pisang & 3053 & 3312 & 8.48 \\
\hline 7 & Kesemek & 7905 & 7500 & 5.12 \\
\hline \multicolumn{7}{|c|}{ Rata-rata selisih harga (\%) } & $\mathbf{5 . 6 4}$ \\
\hline
\end{tabular}

Gambar 2 dan 3 menunjukkan salah satu hasil pengenalan dan prediksi 1 buah dan 4 buah jeruk. Di masing-masing gambar, gambar sebelah kiri adalah buah yang diuji sedang gambar sebelah kanan adalah hasil pengenalan dan prediksi buah oleh sistem. Kotak merah menunjukkan buah yang terdeteksi oleh sistem. Sistem berhasil mengenali, memprediksi berat dan harga buah jeruk baik untuk buah jeruk 1 buah dan 4 buah.

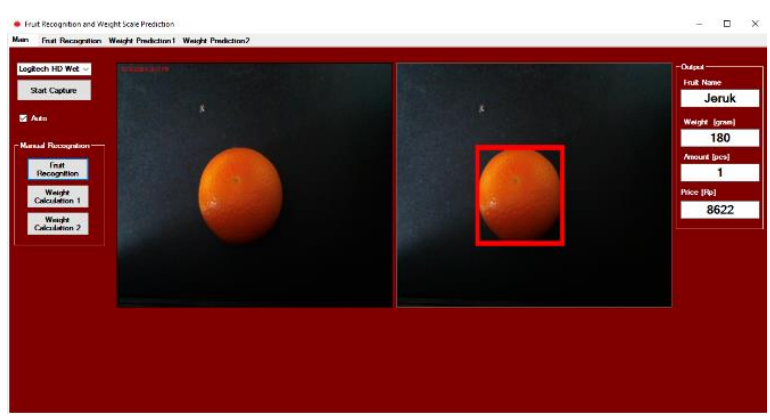

Gambar 2: Hasil pengenalan dan prediksi 1 buah jeruk

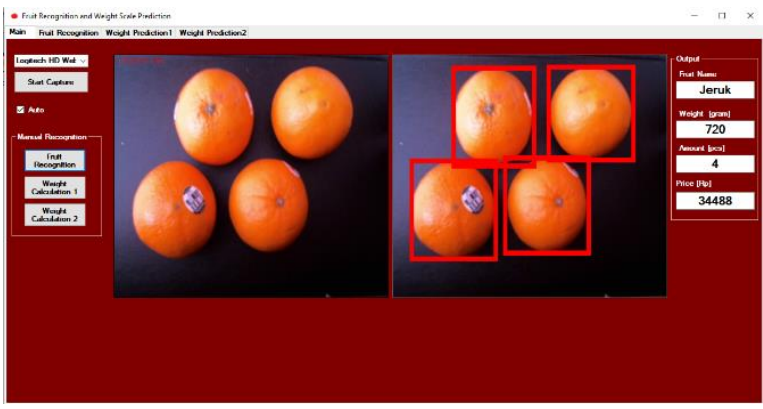

Gambar 3: Hasil pengenalan dan prediksi 4 buah jeruk

\section{Kesimpulan}

Dalam penelitian ini telah berhasil dikembangkan sistem yang menjawab kebutuhan akan sistem yang dapat membuat perkiraan berat dan harga buah. Proses perkiraan berat buah dilakukan dengan perhitungan jumlah pixel dan dianalisa menggunakan persamaan regresi. Hasil perkiraan berat buah ini menghasilkan eror berat rata-rata $4.44 \%$. Sementara proses perkiraan harga buah didapat dari perkiraan bobot buah dikalikan harga per berat buah masing-masing. Hasil perkiraan berat buat ini menghasilkan eror berat ratarata $5.64 \%$

Penelitian ini masih perlu dikembangkan terutama untuk menjawab beberapa buah yang mempunyai kemiripan bentuk, warna dan dimensi. Selain itu tantangan terjadi ketika buah bertumpuk sehingga buah yang satu menutup dengan buah yang lain baik sebagian atau seluruhnya. Untuk mengatasi hal ini diperlukan kamera lain yang dapat mendeteksi di arah yang berbeda. Tantangan lainnya adalah sistem yang real time. Sistem ini mengharuskan peneliti untuk memperhatikan segala macam kondisi termasuk kondisi lingkungan di sekitar pengukuran dan pengenalan. Karena ini akan berpengaruh pada hasil deteksi dan pengenalan. Semua tantangan ini menjadi pekerjaan yang tersisa untuk pengembangan selanjutnya.

\section{Daftar Pustaka}

[1] C.C. Teoh and A.R. Syaifudin, "Image processing and analysis techniques for estimating weight of Chokanan mangoes", Jurnal of Tropical Agricultural and Food Science, pp. 183- 190. 35(1). 2007

[2] P. Poonnoy dan T. Chum , "Estimation of Sushi Shrimp Weight Using Image Analysis Technique and Non-linear Regression Models", Proceding of International conference of agricultural engineering, 2012. 
[3] S. Behera, S. Sangita dan A. Rat, "Image Processing Based Detection \& Size Estimation of Fruit on Mango Tree Canopies", International Journal of Applied Engineering Research, 13(4), 2018.

[4] I.K. Mudana, "Pengembangan aplikasi pengkelasan mutu buah tomat berdasarkan bobot buah menggunakan pengolahan citra digital dengan analisis regresi", Kumpulan Artikel Mahasiswa Pendidikan Teknik Informatika (KARMAPATI), 2 (1), pp. 181-195, 2013

[5] O. Comert, M. Hekim dan K. Adem, "Weight and diameter estimation using image processing and machine learning techniques on apple images", International Journal of Engineering Research and Development, 9(3), 2017.

[6] A. Kadouf and M. Mustafah, "Colour-based object detection and tracking for autonomous
Quadrotor UAV”, IOP Conference Series: Materials Science and Engineering, vol 53(1), 2013.

[7] B. Sugandi, "Deteksi dan Pelacakan Wajah Berdasarkan Warna Kulit Menggunakan Partikel Filter", Jurnal Rekayasa Elektrika, vol 14(2), 2018

[8] K. Yudhistiro, "Menghitung Obyek 2D Menggunakan Connected Component Labeling", Seminar Nasional Sistem Informasi, 2017

[9] N. Wood, E. Abuh dan A. Robert, "Development of a pineapple fruit recognition and counting system using digital farm image, Journal of Computing \& ICT Reference, 12(2), pp 131-139, 2019

[10]W. Qureshi, A. Payne, K. Walsh, dan M. Dailey, "Machine vision for counting fruit on mango tree canopies", Precision Agriculture, 18, pp. 224-244, 2017. 